\title{
Structure of the central Terror Rift, western Ross Sea, Antarctica
}

\author{
Jerome Hall, ${ }^{1}$ Terry Wilson, ${ }^{1}$ and Stuart Henrys ${ }^{2}$ \\ ${ }^{1}$ School of Earth Sciences, 125 S. Oval Mall, Ohio State University, Columbus, OH 43210-1522, USA \\ ${ }^{2}$ GNS Science, I Fairway Drive, Avalon, Lower Hutt, PO Box 30-068, New Zealand
}

\begin{abstract}
The Terror Rift is a zone of post-middle Miocene faulting and volcanism along the western margin of the West Antarctic Rift System. A new seismic data set from NSF geophysical cruise NBP04-01, integrated with the previous dataset to provide higher spatial resolution, has been interpreted in this study in order to improve understanding of the architecture and history of the Terror Rift. The Terror Rift contains two components, a structurally-controlled rollover anticlinal arch intruded by younger volcanic bodies and an associated synclinal basin. Offsets and trend changes in fault patterns have been identified, coincident with shifts in the location of depocenters that define rift sub-basins, indicating that the Terror Rift is segmented by transverse structures. Multiple phases of faulting all post-date $17 \mathrm{Ma}$, including faults cutting the seafloor surface, indicating Neogene rifting and possible modern activity.

Citation: Hall, J.M., T.J. Wilson, and S. Henrys (2007), Structure of the central Terror Rift, western Ross Sea, Antarctica, in Antarctica: A Keystone in a Changing World - Online Proceedings of the 10th ISAES, edited by A.K. Cooper and C.R. Raymond et al., USGS Open-File Report 2007-1047, Short Research Paper 108, 5 p.; doi:10.3133/of2007-1047.srp108
\end{abstract}

\section{Introduction}

The Antarctic continent has been almost entirely surrounded by rifted passive continental margins and divergent plate boundaries since the Cretaceous, yet there has been continued rifting in the Cenozoic within the West Antarctic rift system (Figure 1). Tectonic models derived from global plate reconstructions and other data predict relative motion between East and West Antarctica (e.g., Cande et al., 2000) in the Cenozoic. Previous studies (Cooper et al., 1987, Salvini et al., 1997) identify the Terror Rift in the western Ross Sea as the zone of most recent deformation within the West Antarctic rift system (WARS), yet the magnitude, timing, or kinematics within the Terror Rift remain poorly constrained.

The Mesozoic-Cenozoic WARS occurs beneath the Ross Embayment, located between the Transantarctic Mountains on the East Antarctic side and Marie Byrd Land in West Antarctica (Figure 1). The main phase of crustal extension across the rift has been assigned to the Late Cretaceous between 105 and $85 \mathrm{Ma}$ (Lawver and Gahagan, 1994), and is related to breakup and onset of oceanic spreading between Australia, New Zealand and Antarctica (Cooper et al., 1987; Behrendt et al., 1991; Fitzgerald, 2002). The Cenozoic was a time of renewed extension within the WARS, which was largely limited to the western Ross Sea (Cooper et al., 1987).

The Terror Rift, originally defined by Cooper et al. (1987) based on sparse seismic reflection profiles, is a narrow zone $(\sim 70 \mathrm{~km}$ wide) inside the pre-existing Victoria Land Basin, that stretches between the active Mt. Melbourne and Mt. Erebus volcanoes (Figure 1). It is characterized by abnormally high heat flow (Della Vedova et al., 1995), thin crust (Busetti et al., 1999, Trey et al., 1999), and anomalously slow upper mantle seismic velocities (Bannister et al., 2000). The Terror Rift was defined to have two parts, the down-faulted Discovery Graben and the adjacent magmatically-intruded and folded Lee Arch (Cooper et al., 1987). The presence of faults cutting the seafloor has led to the interpretation that fault motions in the Terror Rift may be continuing to the present (Behrendt, 1991; Salvini and Storti, 1999; Rossetti et al., 2006).

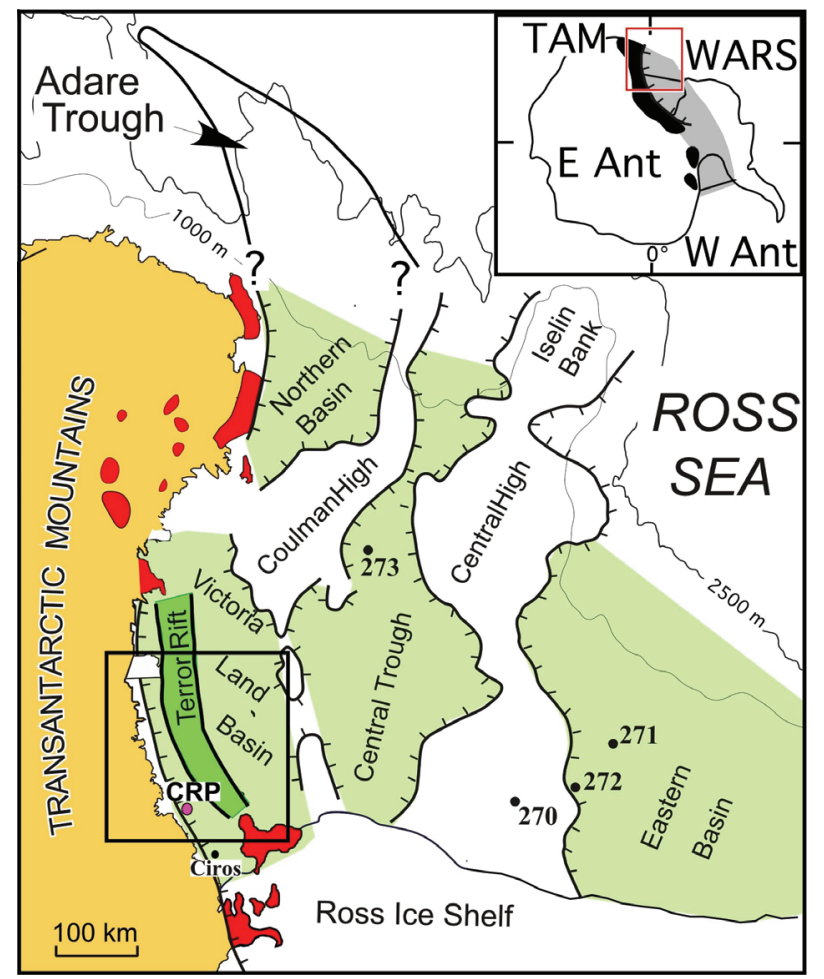

Figure 1. Overview of study area showing location of the Terror Rift in relation to regional tectonic features. Red shading indicates Cenozoic volcanic rocks, black dots represent drillholes and the black box marks the area of Figure 2. Inset map shows setting relative to the West Antarctic rift system (WARS), the Transantarctic Mountains (TAM) and East and West Antarctica. 
The remote location and difficult sea ice conditions in the western Ross Sea have resulted in sparse geophysical surveys in the region, so that data on fault geometries, kinematics and timing in the region have been limited. In early 2004, an NSF-supported marine geophysical survey (NBP04-01) was conducted in the western Ross Sea aboard the RVIB Nathaniel B. Palmer (Wilson et al., 2004). The goal of the cruise was to gain a better understanding of the kinematics and ages of the neotectonic events of the Terror Rift through acquisition of multi-channel and single-channel reflection seismic, magnetic, gravity, and bathymetric data. The focus of the study reported herein is on seismic lines over the central sector of the Terror Rift, where abundant faulting and volcanic features are present. The goals of this study are to map the fault patterns and subsurface geometries in the area, to provide age constraints for the activity of the Terror Rift, and to integrate these results with previous datasets and interpretations for the rift history of the western Ross Sea region.

\section{Seismic data and methods}

The NBP04-01 geophysical cruise acquired 2500 total $\mathrm{km}$ of multi- and single-channel seismic line data during January-February of 2004 (Wilson et al., 2004). Seismic data processing was undertaken on-ship and post-cruise by Stuart Henrys and Huw Horgan of the Institute of Geological and Nuclear Sciences (GNS) of New Zealand using the proprietary software, CLARITAS. The NBP0401 data were integrated with seismic data from previous studies in the region, made available through the SCAR Antarctic Seismic Data Library System (http://dbserver.ogs.trieste.it/SDLS/), including surveys conducted by the USGS, by the OGS within the Italian National Antarctic Research Program, and by prior NSFsponsored cruises on the RVIB N.B Palmer (Figure 2). All the seismic reflection profiles in the southwestern Ross

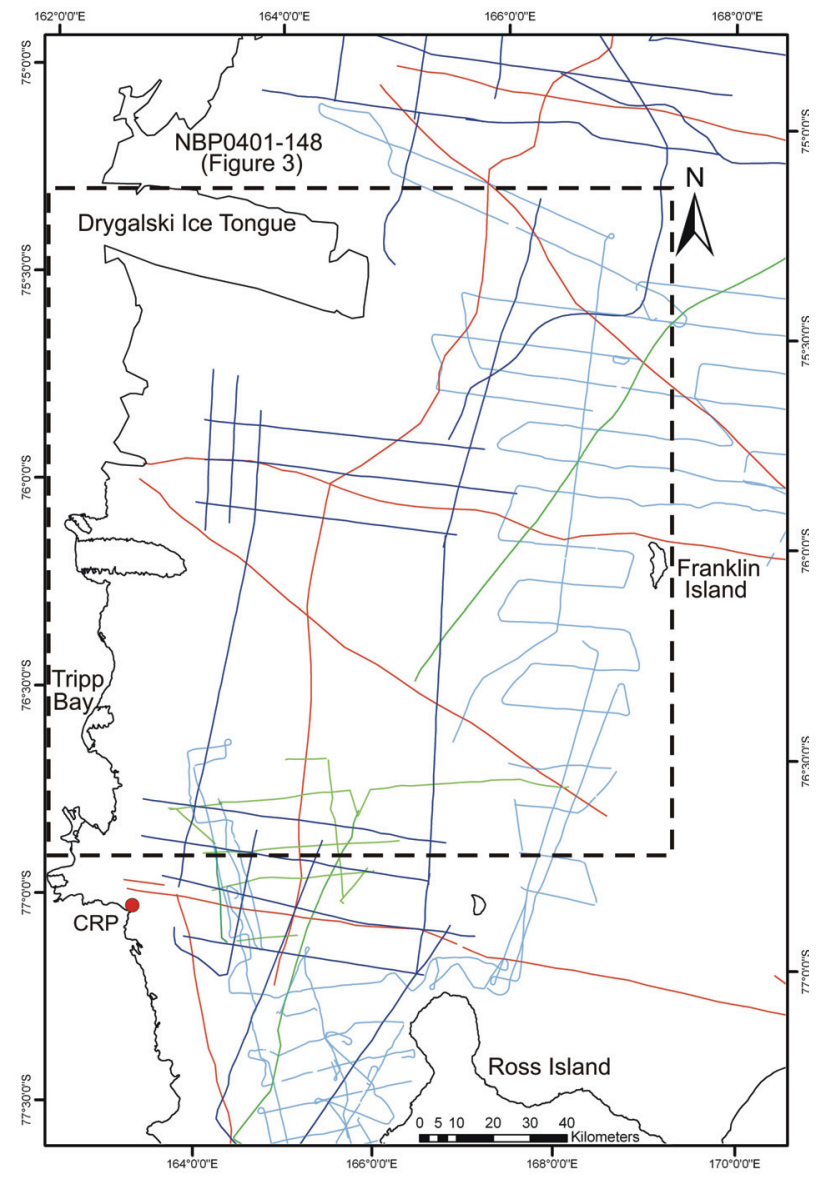

Figure 2. Map of study area showing the distribution of seismic lines used for this study. Colors indicate data source, Light Blue: NBP0401; Red: USGS Lines; Dark Blue: Italian Lines; Green: Other NSF Cruises. Dashed box indicates the map area shown in Figure 4.

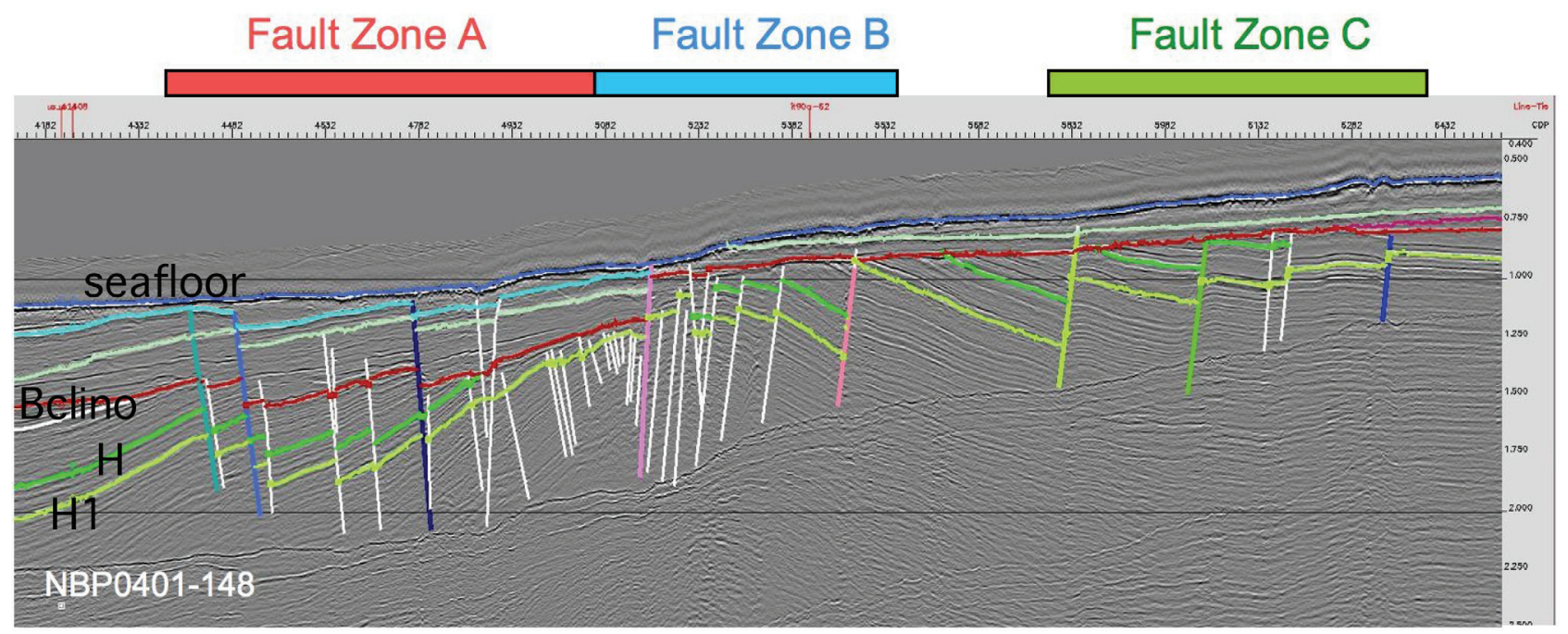

Figure 3. Seismic profile of line NBP0401-148, across the Lee Arch, interpreted as a rollover anticline, showing the major seismic horizons mapped in this study: Bclino, H, and H1 (extended from Fielding et al. (2006)). Colored faults have been correlated regionally. Fault zones A, B, and C are regional zones mapped on Figure 4. 


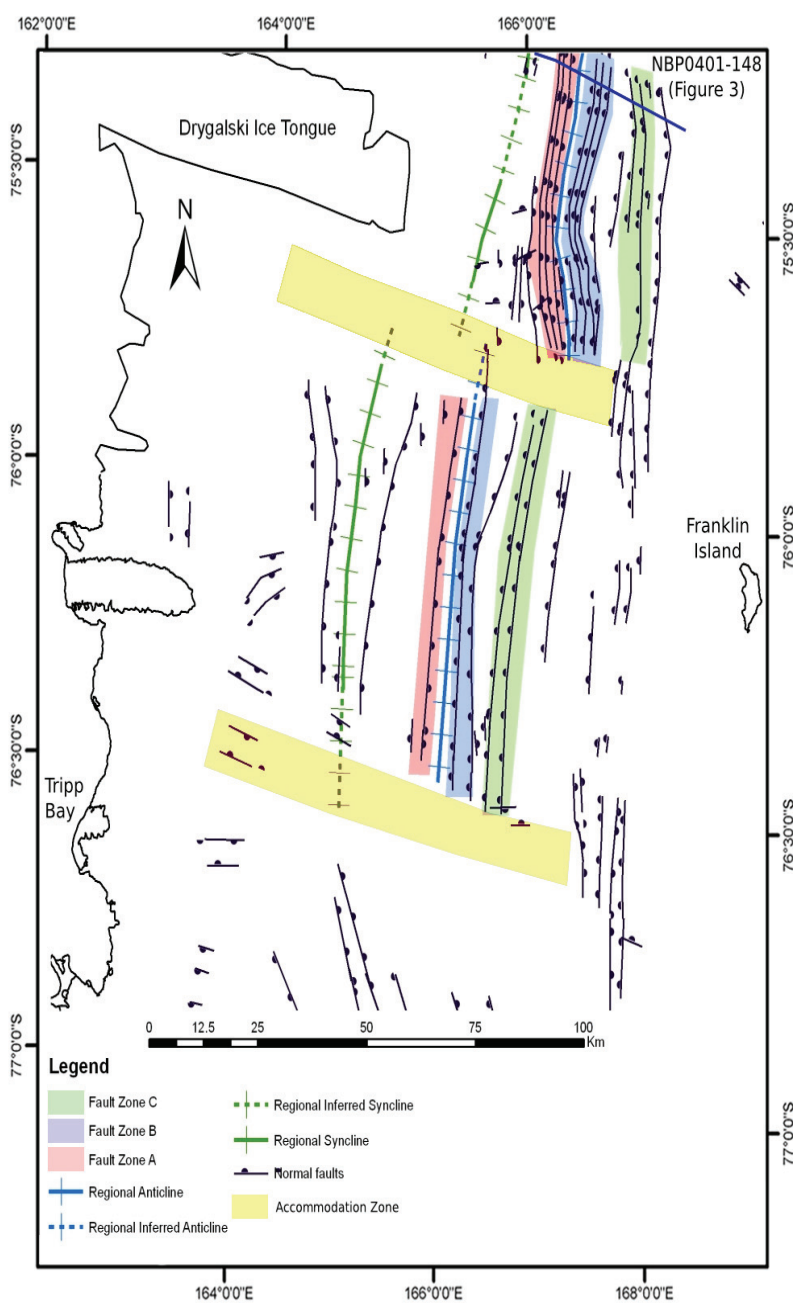

Figure 4. Regional structural map of the central Terror Rift as interpreted by this study. The regional anticline and syncline correspond to the Lee Arch and Discovery Graben mapped by Cooper et al. (1987); this study documents segmentation and offset of these features along transverse accommodation zones.

Sea over and adjacent to the central Terror Rift were interpreted in this study using the Schlumberger Geoframe software suite. Faults were mapped on each profile and, where possible, correlated between profiles. Three regional seismic reflectors, originally defined and mapped by Fielding et al. (2006) and Whittaker (2005), were correlated throughout the seismic grid. Prominent, younger seismic horizons marking unconformities, and intrusive volcanic bodies of the McMurdo Volcanic Group, were also mapped in this study.

\section{Structural patterns of the central Terror Rift Rift structure}

Faulting occurs throughout the study area, but is most concentrated in a well-defined structural zone in the vicinity of Drygalski Ice Tongue. Nearly all identified faults have normal sense separation of reflectors (Figure 3). No reverse faults have been recognized within the study area. The majority of normal faults are steep in angle $\left(60^{\circ}-90^{\circ}\right)$ and have relatively low offset magnitude, many very close to the resolution limit of the seismic system. The largest magnitude fault offsets within the study area are 800-1000 ms ( 800-1000 meters). Faulting with the largest magnitude offset is found in two areas, along and to the east of a regional anticlinal Lee arch. Both major and minor normal faults strike northsouth or north-northeast.

The major regional structural elements in the architecture of the central Terror Rift are a faulted anticline and syncline pair that trend north-south through the study area (Figs. $3 \& 4$ ). The anticline is associated with two major normal fault zones (zones $\mathrm{A}$ and $\mathrm{B}$ on Figure 3), that bound the Lee Arch. A third large-offset fault zone to the east of the anticline (zone $\mathrm{C}$ on Figure 3 ) is the likely candidate for a boundary fault system controlling the overall system architecture, causing stratal tilt and the rollover anticline interpreted for the Lee Arch structure (Hall, 2006). The paired syncline to the west of the anticlinal arch contains relatively little faulting, and is the main depocenter for sediments within the Terror Rift. To the south of the Drygalski Ice Tongue region, the regional arch and syncline, and their associated fault zones, abruptly change position, shifting relatively westward (Figure 4). Further south, offshore of Tripp Bay, the regional structures change to a northwestsoutheast trend. These changes in position and trend are interpreted to mark transverse accommodation zones that divide the Terror Rift into discrete structural segments.

The dominant mode of deformation in the central Terror Rift is extensional normal faulting. The regional north-south normal fault trend (Figure 4) indicates extension across the rift is east-west in direction. Only a few, negative flower structures have been recognized in this study. The flower structures that are present are mostly apparent on lines oriented north-south, suggesting generally east-west trending strike-slip structures. These strike-slip-related flower structures are located within the inferred accommodation zones evident from the offset of the rift faults and basins, consistent with these zones marking transfer structures between rift segments.

\section{Rift stratigraphy}

Horizons denoted "H", "H1", and "Bclino" (Figure 3) were mapped throughout the study area. These horizons represent major regional unconformities of special importance as they provide relative age constraints on faulting events within the Terror Rift. These seismic horizons merge westward into a composite unconformity, hence are only constrained to be younger than $17 \mathrm{Ma}$, the youngest strata cored by the Cape Roberts Project drillhole (Fielding et al., 2006; Henrys et al., 2007). Thickness changes between seismic horizons denoted ' $\mathrm{H}$ ' and 'H1' (Figure 3) indicate deposition synchronous with faulting and this is taken as the onset of Terror Rift deformation (Fielding et al., 2006). Spatial isopach gridding of the strata between the seafloor and the "H1" horizon demonstrates that fault patterns of the rift control stratal thickness, and show thickening of sediments into 
the synclinal basin and thinning across the anticlinal arch (Hall, 2006). The Terror Rift stratal package trends northwest-southeast in the vicinity of McMurdo Sound, changing to a north-south trend across the inferred transverse structure offshore of Tripp Bay. The depocenter defined by this stratal package also shows a change in location, stepping eastward across the inferred transverse structure offshore of the Drygalski Ice Tongue. These sub-basins confirm the segmented nature of the Terror Rift mapped from the structural patterns.

Multiple episodes of faulting are shown by the Bclino reflector, which truncates tilted strata of the anticlinal arch and paired syncline and the faults associated with them (Figure 3). Younger faults cut through and displace the Bclino unconformity and younger seismic horizons, and reach the seafloor. Age constraints derived from correlation of regional seismic reflectors with the Cape Roberts Project drillcore indicate that all of this deformation must be younger than $17 \mathrm{Ma}$ (Fielding et al., 2006).

\section{Discussion}

The Terror Rift was mapped by Cooper et al. (1987) as a sinuous rift defined by graben-horst structures and by Salvini et al. (1997) as a transtensional basin linked with strike-slip faults crossing northern Victoria Land. These previous interpretations of the Terror Rift did not have seismic lines with sufficient spatial density to fully define the rift architecture. The Terror Rift contains two components, a structurally-controlled north-south trending rollover anticlinal arch and an associated synclinal basin. This architecture is not associated with any volcanic intrusions in the vicinity of Drygalski Ice Tongue, showing that the structure was not formed by doming related to emplacement of the volcanic bodies. An increasing component of volcanism, including feeder dikes to seafloor vents and larger, subvolcanic intrusions, intrudes the Terror Rift structure southward, toward Ross Island. Offsets and trend changes in fault patterns, coincident with shifts in the location of depocenters that define rift sub-basins, indicate that the Terror Rift is segmented by transverse structures.

The dominant mode of deformation in the central Terror Rift is extensional normal faulting. Positive and negative flower structures related to strike-slip faulting have been previously interpreted at several locations within the study area (Salvini et al. 1997). Based on the improved seismic data set used in this study, many of the previously defined flower structures are better interpreted as grabens or have poorly-defined geometry because they occur in areas of poor data quality. We find little evidence for strike-slip faulting within this zone of the Terror Rift, indicating limited transtension within the rift in this region.The regional NNE-SSW normal fault trend and inferred WNW-ESE transverse accommodation zone orientation indicate orthogonal extension across the rift in a WNW-ESE direction.

\section{Summary}

The Terror Rift, located within the Victoria Land Basin in the western Ross Sea, has the most recent fault activity within the WARS (Cooper et al., 1987). New seismic data over the central Terror Rift better resolves the architecture and timing of rift activity. Evidence from our new analysis shows the Terror Rift to be composed of segmented, offset sub-basins, bounded by transverse structures coeval with rifting. The central Terror Rift underwent east-west rifting, without a significant transtensional component. Rift-related volcanism, including feeder dikes and subvolcanic intrusions, postdate the main phase of rift development in the central Terror Rift. All rift deformation post-dates $17 \mathrm{Ma}$. There were multiple phases of faulting, and faults cutting the seafloor surface suggest possible modern activity.

Acknowledgements. Captain Mike Watson, the RPSC technical staff, the crew of the RVIB Nathanial B Palmer, and the shipboard science team are thanked for their support in acquiring data during NBP04-01. The NBP04-01 cruise and subsequent data analysis by TJW and JH was supported by The National Science Foundation (grant ANT-0125624). SAH acknowledges support from the Royal Society of New Zealand Marsden Fund. Thanks to Fred Davey and Martina Busetti for constructive reviews that improved this paper and also to Alan Cooper and Paul Fitzgerald for editorial handling.

\section{References}

Bannister, S., F. J. Davey, B. Kennett, (2000), Lithospheric structure of the TransAntarctic Mountains, Antarctica, from broadband seismic data. Geological Society of New Zealand Miscellaneous Publication 108A. Lower Hutt, Geological Society of New Zealand.

Behrendt, J.C., W. E. LeMasurier, A. K. Cooper, F. Tessensohn, A. Tréhu, and D. Damaske, (1991), Geophysical studies of the West Antarctic rift system. Tectonics, 10, 1257-1273.

Busetti, M., G. Spadini, F. M. Van der Wateren, S. Cloetingh, and C. Zanolla, (1999), Kinematic modeling of the West Antarctic Rift System, Ross Sea, Antarctica. Global and Planetary Change, 23/1-4, 79-103.

Cande, S. C., J. M. Stock, R. D. Mueller, and T. Ishihara, (2000), Cenozoic motion between East and West Antarctica. Nature, 404, 145-150.

Cooper, A. K., F. J. Davey, and J. C. Behrendt, (1987), Seismic stratigraphy and structure of the Victoria Land basin, western Ross Sea, Antarctica. In: Cooper A.K. and Davey F.J. eds., The Antarctic Continental Margin: Geology and Geophysics of the western Ross Sea. Published by theCircum-Pacific Council for Energy and Mineral Resources, Houston, Texas, 5B, 27-66.

Della Vedova, B., G. Pellis, A. K. Cooper, J. Makris, H. Trey, J. Zhang, ACRUP Working group, (1995), Crustal Structure of the Transantarctic Mountains at 76 degrees south, western Ross Sea area. VII Int. Symp. of Antarctic Earth Science, Abstracts Vol. 107.

Fielding, C. R., S. A. Henrys, and T. J. Wilson, (2006), Rift history of the western Victoria Land Basin: a new perspective based on integration of cores with seismic reflection data., in D. K. Futterer, D. Damaske, G. Kleinschmidt, M. H., and T. F., eds., Antarctica: Contributions to Global Earth Sciences: Berlin Heidelberg New York, Springer-Verlag, p. 307-316.

Fitzgerald, P.G., (2002), Tectonics and landscape evolution of the Antarctic plate since the breakup of Gondwana, with an emphasis on the West Antarctic Rift System and the Transantarctic Mountains. In: Gamble, J.A., D. N. B. Skinner, and S. Henrys, eds., Antarctica at the close of a millennium, Royal Society of New Zealand Bulletin, 35, 251-259.

Hall, J. M., 2006. Structural evolution of the Terror Rift, western Ross Sea, Antarctica: Interpretation from 2D Reflection Seismic. Master's Thesis, The Ohio State University, Columbus, Ohio.

Henrys, S.A., Bucker, C.J., Niessen, F., Bartek, L.R., 2001. Correlation of seismic reflectors with the CRP-3 drillhole, Victoria Land Basin, Antarctica. Terra Antartica 8, 127-136. 
Henrys SA, Wilson TJ, Whittaker JM, Fielding CR, Hall JM, Naish T. 2007. Tectonic History of mid-Miocene to present, southern Victoria Land Basin, inferred from seismic stratigraphy, in McMurdo Sound, Antarctica. In: Cooper AK, Raymond C.R. et al., editors. Antarctica: A Keystone in a Changing World ? Online Proceedings of the 10th ISAES: USGS Open-File Report 2007-1047, Short Research Paper 049.

Lawver, L.A. and L. M. Gahagan, (1994), Constraints on Timing of Extension in the Ross Sea Region. Terra Antarctica, 1/3, 545-552.

Rossetti F., F. Storti, M. Busetti, F. Lisker, G. Di Vincenzo, A. L. Läufer, S. Rocchi and F. Salvini (2006). Eocene initiation of Ross Sea dextral faulting and implications for East Antarctic neotectonics. Journal of the Geological Society, 163, 119-126.

Salvini, F. and F. Storti, (1999), Cenozoic tectonic lineaments of the Terra Nova Bay region, Ross Embayment, Antarctica. Global and Planetary Change, 23/1-4, 129-144.
Salvini, F., G. Brancolini, M. Busetti, F. Storti, F. Mazzarini and F. Coren, (1997),Cenozoic geodynamics of the Ross Sea region, Antarctica: Crustal extension, intraplate strike-slip faulting and tectonic inheritance. Journal of Geophysical Research, 102/B11, 24,669-24,696.

Trey, H., A. K. Cooper, G. Pellis, B. Della Vedova, G. Cochrane, G. Brancolini, J. Makris, (1999), Transect across the West Antarctic rift system in the Ross Sea, Antarctica. Tectonophysics, 301, 61-74.

Whittaker, J., (2005), Cenozoic Structural and Stratigraphic History of McMurdo Sound, Antarctica. Master's Thesis, Victoria University of Wellington, Wellington, New Zealand.

Wilson, T.J, Lawver, L.A., Henrys, S.A., Mukasa, S., Horgan, H., Weiderspahn, M., Davis, M., Whittaker, J., Lowe, A., Watson, M. (2004), Cruise Report NBP0401 19 January to 18 February 2004 McMurdo Station to McMurdo Station, Ross Sea Antarctica, Institute of Geological \& Nuclear Sciences science report 2004/03. 85p. 